\title{
Regeneration of Tetraploid Muskmelons from Cotyledons and Their Morphological Differences from Two Diploid Muskmelon Genotypes
}

\author{
G. Fassuliotis ${ }^{1}$ \\ Department of Plant Pathology and Physiology, Clemson University, Clemson, SC 29634 \\ B.V. Nelson ${ }^{2}$ \\ U.S. Department of Agriculture, Agricultural Research Service, U.S. Vegetable Laboratory, 2875 \\ Savannah Highway, Charleston, SC 29414 \\ Additional index words. Cucumis melo, somaclonal variation, pollen, stomates, chloroplasts, cytology, chromosomes
}

\begin{abstract}
Gulfstream' and 'Charentais' muskmelons (Cucumis melo. L.) plants were regenerated by in vitro culture to increase their genetic variability for resistance to root-knot nematodes (Meloidogyne spp.). While no genetic variability for root knot resistance was found, regenerated plants exhibited other traits that varied from the donor cotyledons. Chromosome counts confirmed that $>75 \%$ of the somaclonal variants were tetraploid $(2 \mathrm{n}=24 ; 4 \mathrm{n}=$ 48). Tetraploids consistently exhibited micro- and macroscopic morphological changes that enabled distinction between tetraploids and diploids without chromosome counts; tetraploids contained enlarged stomates with more chloroplasts in the guard cells and pollen with a high percentage of square-appearing shapes. Tetraploids exhibited distinctive macroscopic morphological changes, including differences in leaf structure, fruit shape, blossom-end scar, number of vein tracts, and seed size.
\end{abstract}

Somaclonal variation derived from cell and tissue culture can be useful to plant breeders as an important source of variability for plant improvement. Such variation is apparently widespread among many of the plant families investigated, and it is expressed at a comparatively high frequency for a diverse number of traits (Evans and Sharp, 1986; Larkin and Scowcroft, 1981). One of the most important uses for somaclonal variants is the identification of disease-resistant selections. In the cucurbits, there is much genetic variation for horticultural traits within the species but little or no variation for resistance to root-knot diseases. Somaclonal variation was proposed as a means to discover unique variants for resistance to root-knot nematodes (Fassuliotis, 1987).

Although the culture of muskmelon cells and tissues had been recalcitrant, recent research has enhanced the capacity for culture. However, cotyledons have been the only tissues from which plants have been regenerated in vitro with some consistency (Moreno and Roig, 1990). Somaclonal variants for some characters of 'Gulfstream' plants regenerated from cotyledons were reported by Fassuliotis (1991). In more recent work, we observed somaclonal variation among the regenerants from 'Charentais' muskmelon cotyledons. This report describes the variant plants regenerated from cotyledon explants of 'Charentais' with additional observations on the 'Gulfstream' regenerants.

\section{Materials and Methods}

'Gulfstream' seed were obtained and increased from the U.S. Vegetable Laboratory working collection. 'Charentais' seed were

\footnotetext{
Received for publication 30 Sept. 1991. Accepted for publication 18 May 1992. Technical contribution no. 3186 of the South Carolina Agricultural Experiment Station. Mention of a trade name or proprietary product does not constitute a warranty or guarantee by the U.S. Dept. of Agriculture nor does it imply the exclusion of other products that may also be suitable. The cost of publishing this paper was defrayed in part by the payment of page charges. Under postal regulations, this paper therefore must be hereby marked advertisement solely to indicate this fact.

${ }^{1}$ Visiting Professor. Present address: 75 East Bay St., Charleston, SC 29401. ${ }^{2}$ Biological Laboratory Technician.
}

donated by Hollar Seeds, Rocky Ford, Colo. Seeds were surface-sterilized in $2.5 \%$ sodium hypochlorite solution for $20 \mathrm{~min}$ and rinsed three times with sterile distilled water. They were germinated on $0.8 \%$ water agar in $9.0-\mathrm{cm}$ petri dishes at $27 \mathrm{C}$ in darkness for 4 days and then transferred to a $25 \mathrm{C}$ growth room illuminated for $16 \mathrm{~h}$ daily with $63 \mu \mathrm{mol} \cdot \mathrm{m}^{-2} \cdot \mathrm{s}^{-1}$ from cool-white fluorescent lamps for an additional 4 days.

The cotyledon regeneration media consisted of MS salts (Murashige and Skoog, 1962) supplemented with B5 vitamins (Gamborg et al., 1968), $100 \mathrm{mg}$ myo- inositol/liter, 3\% sucrose, and $5 \mu \mathrm{M}$ benzylamino-purine (BAP) for 'Charentais' and 10 $\mu \mathrm{M}$ indole-3-acetic acid (IAA) and $5 \mu \mathrm{M}$ BAP for 'Gulfstream'. The $\mathrm{pH}$ was adjusted to 5.8 with $1 \mathrm{~N} \mathrm{KOH}$ or $1 \mathrm{~N} \mathrm{HCl}$ and $0.7 \%$ agar was added. The medium was autoclaved at $120 \mathrm{C}$ at $105 \mathrm{kPa}$ for $15 \mathrm{~min}$, and $5 \mathrm{ml}$ was dispensed into $20-\mathrm{ml} \mathrm{scin}-$ tillation vials. Expanded green cotyledons were excised $2 \mathrm{~mm}$ beyond the point of attachment, transferred to the culture vials, and incubated at $25 \mathrm{C}$ under $19 \mu \mathrm{mol} \cdot \mathrm{m}^{-2} \cdot \mathrm{s}^{-1}$.

Plants. Plants regenerated from cotyledons were identified as $R_{0}$. Succeeding self-fertilized generations were identified as $R_{1}$ and $R_{2} \cdot R_{0}$ plants were removed from their culture vessels and washed gently in running tap water to remove the agar medium. The plants were transferred to $150-\mathrm{ml}$ pots in a soilless compost (Jiffy Mix) and conditioned under an inverted polyethylene bag for 1 week. Parental seedlings and regenerated plants were grown in the greenhouse in benches or in 18.9-liter pots, depending on available space. Using standard pollination procedures for muskmelons, plants were selfed to obtain one or two fruit from each plant.

Classification of regeneratedplants. Regenerated plants were described and classified by inspection of gross morphological traits. Cytological and microscopic anatomical observations were made to confirm subjective observations.

Pollen. Pollen shape and viability were determined by microscopic examination after staining with acetocarmine. Onehundred pollen grains from each of two flowers for each plant were scored and averaged.

Cytology. Root tips growing through the drainage holes of potted plants were collected, pretreated with 0.002 м 8-hy- 


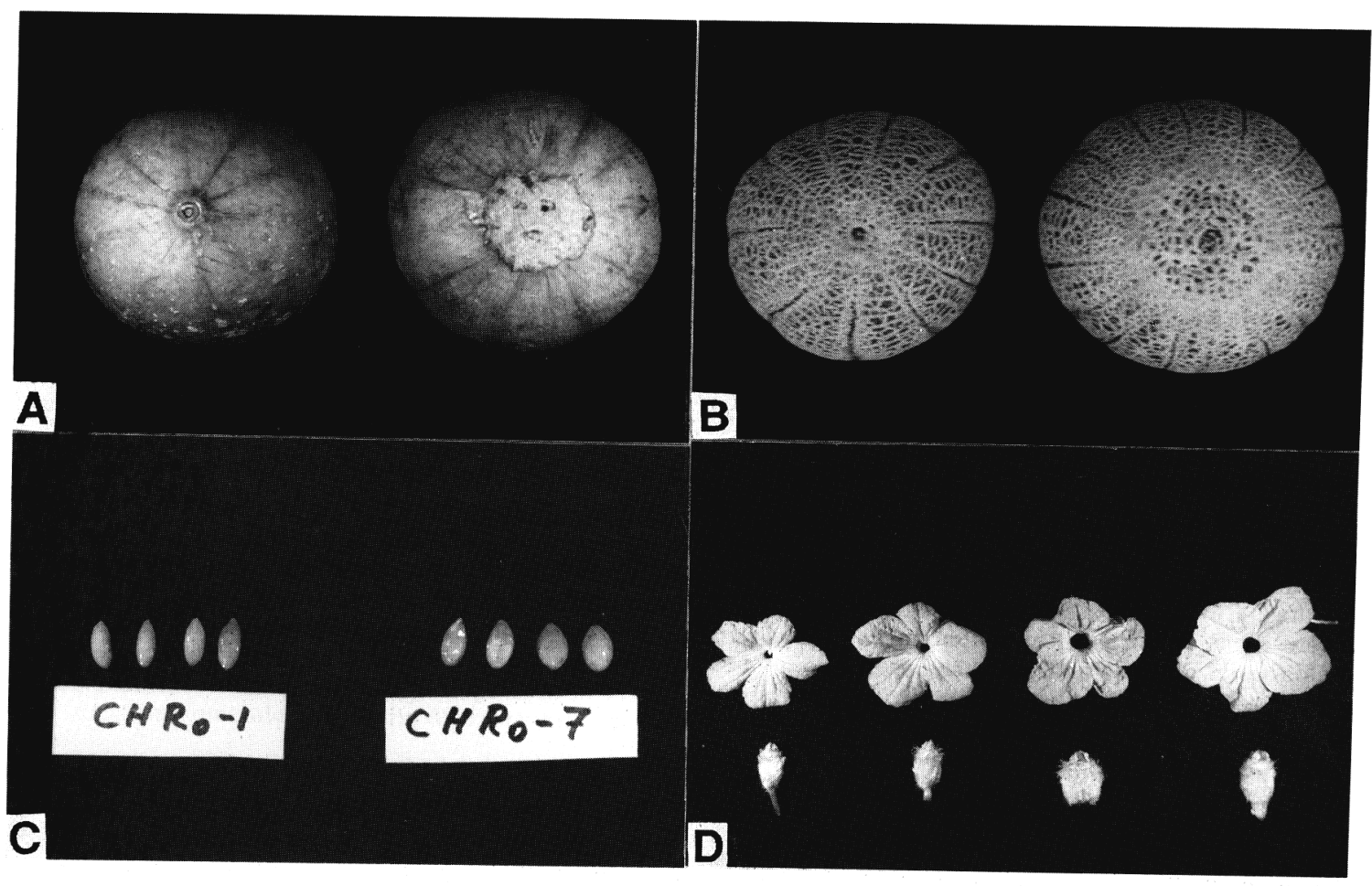

Fig. 1. 'Charentais' (A) and 'Gulfstream' (B) muskmelons showing large blossom-end scar of tetraploid fruit (right in each photo) from plants regenerated from cotyledons; (C) comparative size and shape of seeds recovered from diploid (left) and tetraploid (right) melons; (D) corollas removed from ovaries of diploid (left) and tetraploid (right) 'Gulfstream' melons showing larger size of corolla and ovaries of tetraploid plants (right).

Table 1. Characteristics of muskmelons regenerated from cotyledons.

\begin{tabular}{|c|c|c|c|c|c|c|c|c|}
\hline Genotype & $\begin{array}{c}\text { Stomate } \\
\text { length } \\
(\mu \mathrm{m})\end{array}$ & $\begin{array}{c}\text { No. } \\
\text { chloroplasts }\end{array}$ & Ploidy & $\begin{array}{l}\text { Blossom- } \\
\text { end scar }\end{array}$ & $\begin{array}{c}\text { Vein } \\
\text { tracts }\end{array}$ & $\begin{array}{c}\text { Pollen } \\
\text { viability } \\
(\%)\end{array}$ & $\begin{array}{c}\text { Pollen } \\
\text { shape }^{z} \\
(\%) \\
\end{array}$ & Seed \\
\hline Gulfstream & $20.3 \mathrm{~g}^{\mathrm{y}}$ & $7.27 \mathrm{e}$ & $2 n$ & Small & 10 & 100 & $100 / 0 / 0$ & + \\
\hline $\mathrm{GSR}_{1} 36$ & $22.4 \mathrm{~g}$ & $8.90 \mathrm{e}$ & $2 n$ & Small & 10 & 100 & $100 / 0 / 0$ & + \\
\hline $\mathrm{GSR}_{2} 93$ & $29.50 \mathrm{bc}$ & $15.19 \mathrm{c}$ & $4 n$ & Large & 16 & 97 & $58 / 0 / 42$ & + \\
\hline Charentais & $20.80 \mathrm{fg}$ & $8.57 \mathrm{de}$ & $2 n$ & Small & 10 & 100 & $100 / 0 / 0$ & + \\
\hline $\mathrm{CHR}_{0}-1$ & $23.00 \mathrm{e}^{\circ}$ & $8.50 \mathrm{de}$ & $2 n$ & Small & 10 & 100 & $100 / 0 / 0$ & + \\
\hline $\mathrm{CHR}_{0}-3$ & $24.20 \mathrm{e}$ & $14.20 \mathrm{c}$ & $2 n$ & Small & 10 & 100 & $99 / 0 / 1$ & + \\
\hline $\mathrm{CHR}_{0}-4$ & $30.16 \mathrm{~b}$ & $17.04 \mathrm{~b}$ & $4 n$ & $---x$ & -- & 90 & $20 / 26 / 54$ & - \\
\hline $\mathrm{CHR}_{0}-5$ & $28.16 \mathrm{c}$ & $13.92 \mathrm{c}$ & $4 n$ & -- & -- & 88 & $21 / 19 / 60$ & - \\
\hline $\mathrm{CHR}_{0}-6$ & $25.60 \mathrm{~d}$ & $14.72 \mathrm{c}$ & $4 n$ & Large & 13 & 90 & $14 / 21 / 64$ & + \\
\hline $\mathrm{CHR}_{0}-7$ & $28.96 \mathrm{bc}$ & $15.04 \mathrm{c}$ & $4 n$ & -- & --- & 88 & $3 / 61 / 36$ & + \\
\hline $\mathrm{CHR}_{0}-9$ & $28.96 \mathrm{bc}$ & $14.48 \mathrm{c}$ & $4 n$ & --- & --- & 91 & $48 / 25 / 27$ & - \\
\hline $\mathrm{CHR}_{0}-10$ & $21.76 \mathrm{f}$ & $9.28 \mathrm{~d}$ & $2 n$ & Small & --- & 100 & $51 / 48 / 1$ & + \\
\hline $\mathrm{CHR}_{0}-11$ & $26.40 \mathrm{~d}$ & $13.80 \mathrm{c}$ & $4 n$ & Large & -- &.- & --- & - \\
\hline $\mathrm{CHR}_{0}-16$ & $29.20 \mathrm{bc}$ & $14.30 \mathrm{c}$ & $4 n$ & --- & --- & 95 & $9 / 73 / 18$ & + \\
\hline $\mathrm{CHR}_{0}-18$ & $39.80 \mathrm{a}$ & $24.70 \mathrm{a}$ & $4 n$ & -- & --- & 88 & $29 / 24 / 47$ & - \\
\hline $\mathrm{CHR}_{0}-19$ & $24.20 \mathrm{e}$ & $16.70 \mathrm{~b}$ & $4 n$ & --- & --- & 96 & $18 / 60 / 22$ & - \\
\hline
\end{tabular}

${ }^{2}$ Percentage of triangular/elliptical-round/square-appearing pollen grains.

'Mean separation according to Duncan's-multiple range test $(P=0.05)$.

Indicates that no fruit obtained or no observation on fruit trait or pollen.

droxyquinoline for $4 \mathrm{~h}$ at $21 \mathrm{C}$, and fixed in Carnoy's solution (6 ethanol : 3 chloroform : 1 acetic acid). Carbol fuchsin smears (Kao, 1975) were prepared following standard procedures, and chromosomes were counted under a light microscope at $\times 1000$ magnification.

Stomates and chloroplasts. The third or fourth expanded leaf from the apex was excised. A strip of epidermis was peeled from the leaf with fine forceps, stained with $0.02 \%$ silver nitrate solution, covered with a cover slip, and examined under the microscope at $\times 400$. Stomates with clearly defined boundaries were measured with an ocular micrometer, and the number of black-staining chloroplasts within each pair of guard cells was counted and recorded. Data were subjected to analysis of variance with means separated by Duncan's multiple range test. 


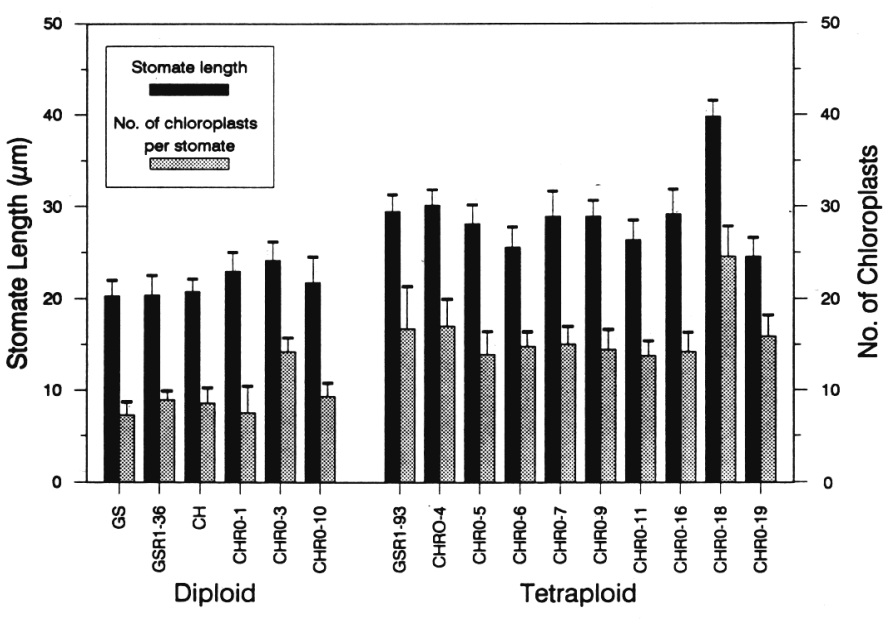

Gulfstream and Charentais Muskmelon Regenerants from Cotyledons

Fig. 2. Distribution of stomate lengths and number of chloroplasts per pair of guard cells for plants regenerated from 'Gulfstream' (GS) and 'Charentais' (CHR) cotyledons.

\section{Results and Discussion}

A friable white callus was initiated around the cut edges of the cotyledon explants of 'Gulfstream' and 'Charentais' after 5 to 7 days in culture on their respective media. The callus differentiated into dark-green nodules, which, after transfer to MS $+0.5 \mu \mathrm{M} \mathrm{BAP}$ for 'Gulfstream' and to MS + $0.1 \mu \mathrm{M} \mathrm{BAP}$ for 'Charentais', produced leaves and shoots within 2 to 3 weeks. These structures were transferred to hormone-free, 1/2 strength, MS basal medium to promote root growth.

A total of six 'Gulfstream' and 19 'Charentais' $\mathrm{R}_{0}$ plants were transferred to the greenhouse. Four 'Gulfstream' and 12 'Charentais' survived and grew to maturity. All of the regenerated plants showed some initial phenotypic variation, but this variation was more pronounced among the 'Gulfstream' plants. One of the four regenerated 'Gulfstream' plants $\left(\mathrm{GSR}_{0} 36\right)$ more closely resembled the parental type than the other three plants $\left(\mathrm{GSR}_{0} 88\right.$, $93,94)$ and was confirmed to be diploid $(\mathrm{n}=24)$. The leaves of $\mathrm{GSR}_{0} 88$, 93, and 94 were large, thick, and leathery with prominent leaf serrations (Fassuliotis, 1991). Chromosome counts from root-tip smears confirmed their tetraploidy. Both perfect and staminate flowers were larger than on the andromonoecious parent 'Gulfstream' (Fig. 1D). The $\mathrm{GSR}_{0}$ fruit from each of these regenerants were round to oval and about one-third the size of fruit from the 'Gulfstream' parent plants. They contained a few viable seed, and the most seed were recovered from $\mathrm{GSR}_{0} 93$. Seeds from tetraploid plants were broader and thicker than those recovered from the diploid plants (Fig. 1C). Viable seed from the $\mathrm{R}_{0} 36,88$, and 94 fruit were largely depleted in tests for susceptibility to the southern root-knot nematode $\mathrm{Me}$ loidogyne incognita Chitwood. Therefore, this report focuses on observations obtained from the $\mathrm{GSR}_{0} 93$ regenerant and its progeny.

After two generations of selfing, the $\mathrm{GSR}_{2} 93$ plants grew as vigorously as the $\mathrm{R}_{0}$ and $\mathrm{R}_{1}$ plants and were verified as tetraploids. The fruit were oblate and contained an enlarged blossom-end scar with an increased number of vein tracts (16 vs. 10) (Fig. 1B).

The 'Charentais' regenerants exhibited the pale-green color typical of the cultivar. Growth of these plants was not as luxuriant as the 'Gulfstream' regenerants and may be attributed to their culture in pots rather than in greenhouse benches. Leaves

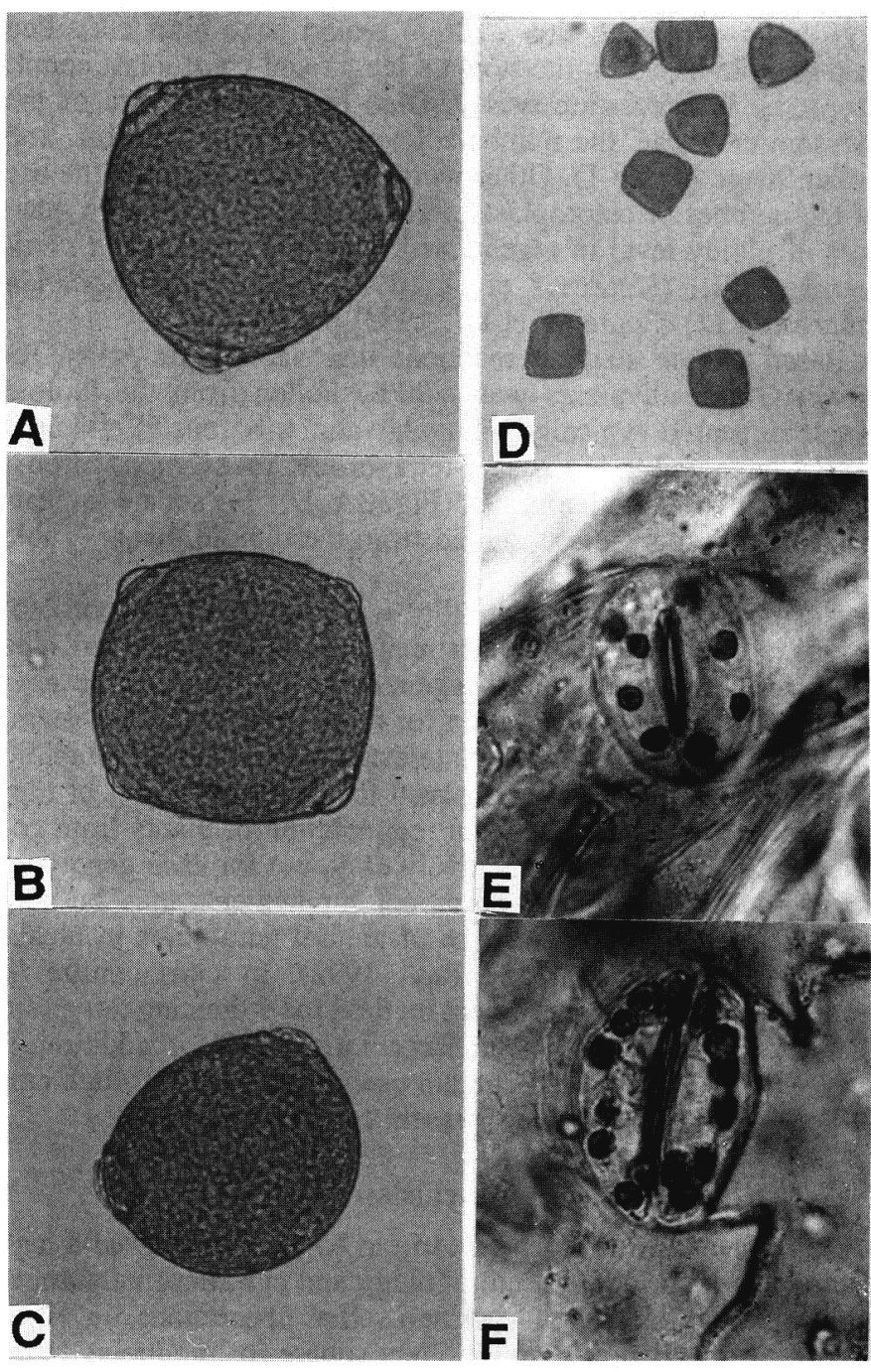

Fig. 3. (A) Typical triangular-appearing shape of pollen grain from diploid muskmelon plants; (B-D) variant pollen grains recovered from tetraploid plants. Square-appearing pollen grains were always recovered from tetraploid plants; (E) stomate from diploid muskmelon leaf containing eight chloroplasts; (F) stomate from a tetraploid leaf showing 16 chloroplasts.

varied from typically 'Charentais'-like to a more sinuate, leathery, and rougher-textured morphology. Plants with large, perfect flowers developed fruit with a prominent, large blossomend scar (Fig. 1A) and more vein tracts (13 vs. 10) and were confirmed to be tetraploid $(4 n=48)$. A recent review article by Moreno and Roig (1990) included a figure of a regenerated tetraploid variant 'Charentais' melon fruit with at least 18 vein tracts.

Figure 2 shows the distribution of stomate lengths and the number of chloroplasts per pair of guard cells for 16 genotypes. The average stomate length was $22.1 \pm 2.15 \mu \mathrm{m}$ for the diploid plants and $29.1 \pm 2.15 \mu \mathrm{m}$ for the tetraploid plants. The average number of chloroplasts per pair of guard cells was $9.4 \pm$ 1.5 for the diploid plants and $16.0 \pm 2.5$ for the tetraploids (Fig. $3 \mathrm{E}$ and F).

Generally, the diploid plants could be differentiated from the tetraploids with these characters, except for one diploid regenerant, $\mathrm{CHR}_{0}-3$, which overlapped into the tetraploid range for 
both traits. Although line $\mathrm{CHR}_{0} 3$ would have been classified as tetraploid based on the stomate length and chloroplast count, its proper classification was verified by the small size of the blossom-end scar, the number of vein tracts on the fruit, and pollen shape (Table 1). Other workers recently reported the use of the number of chloroplasts per pair of guard cells as a measure of ploidy level in regenerated tomato (Lycopersicon esculentum Mill.) (Koorneef et al., 1989) and potato (Solanum tuberosum L.) (Schreiter et al., 1989) plants.

Based on the staining reaction, the viability of pollen recovered from all plants was $>90 \%$. Pollen from the diploid plants appeared typically triangular and triporous. Tetraploid plants contained many square-tetraporous, round-monoporous, or oval-biporous pollen grains (Fig. 3A-D). No square-appearing pollen grains were observed from the diploid plants (Table $1)$.

No differences in susceptibility were found in the root-knot resistance test with the 'Gulfstream' $\mathrm{R}_{0}$ regenerants (no data presented). However, these regenerated lines may serve as a source of new genetic variation for other traits. In recent years, plant breeders have become interested in producing tetraploid muskmelons as potential germplasm for the development of triploid fruit. The methodology for regeneration of plants from cotyledons is available and relatively easy, but for each genotype, some modification in the hormonal supplements may be necessary. Because the occurrence of natural tetraploids in muskmelon is rare (Nugent and Ray, 1992), in vitro culture of cotyledons provides an efficient method for producing tetraploid plants (Adelberg et al., 1990; Fassuliotis, 1991). In addition, it may provide variants that contain useful characters through amplification of gene products present in the diploid plant.

\section{Conclusion}

Muskmelon plants regenerated from cotyledons showed a high frequency of variation in morphology and chromosome number that was inherited for at least two selfed generations. In vitrocultured cotyledons are an excellent source for producing tetraploid plants. The large blossom-end scar, the increased number of vein tracts, and the oblate conformance of the fruit can be used to identify which muskmelon plants are likely tetraploids. Additional confirmation can be obtained from microscopic study of stomate size, number of chloroplasts per pair of guard cells, and pollen shape, thereby minimizing the need for absolute confirmation of ploidy level by chromosome counts.

\section{Literature Cited}

Adelberg, J., B.B. Rhodes, and H.S. Skorupska. 1990. Generating tetraploid melons from tissue culture. HortScience 25:1073. (Abstr.)

Evans, D.A. and W.R. Sharp. 1986. Somaclonal and gametoclonal variation, p. 97-132. In: D.A. Evans, W.R. Sharp, and P.V. Ammirato (eds.). Handbook of plant cell culture, vol. 4. Macmillan, New York.

Fassuliotis, G. 1987. Genetic basis of plant resistance to nematodes, p. 364-371. In: J.A. Veech and D.W. Dickson (eds.). Vistas on nematology. Soc. Nematol., Hyattsville, Md.

Fassuliotis, G. 1991. Somaclonal variants of muskmelon regenerated from cotyledons. Proc. 2nd Intl. Symp. Protected Cultivation of Vegetables in Mild Winter Climates, Iraklion, Crete, Greece, 29 Oct.-3 Nov. 1989. Acta Hort. 287:163-167.

Gamborg, O.L., R.A. Miller, and K. Ojima. 1968. Nutrient requirements of suspension cultures of soybean root cells. Expt. Cell Res. $50: 151-158$.

Kao, K.N. 1975. A nuclear staining method for plant protoplasts, p. 60-62. In: O.L. Gamborg and L.R. Wetter (eds.). Plant tissue culture methods. Natl. Res. Coun. Canada, Prairie Res. Lab., Saskatoon, Saskatchewan, Canada.

Koomeef, J., A.M. van diepen, C.J. Hanhart, A.C. Kieboom-de Waart, L. Martinelli, H.C.H. Schoenmakers, and J. Wijbrandi. 1989. Chromosomal instability in cell- and tissue-cultures of tomato haploids and diploids. Euphytica 43:179-186.

Larkin, P.J. and W.R. Scowcroft. 1981. Somaclonal variation-A novel source of variability from cell cultures for plant improvement. Theor. Applied Genet. 60:197-214.

Moreno, V. and L.A. Roig. 1990. Somaclonal variation in cucurbits, p. 435-464. In: Y.P.S. Bajaj (ed.). Biotechnology in agriculture and forestry. vol. 11. Somaclonal variation in crop improvement I. Springer-Verlag Berlin, Heidelberg.

Murashige, T. and F. Skoog. 1962. A revised medium for rapid growth and bioassay with tobacco tissue culture. Physiol. Plant. 15:473497.

Nugent, P.E. and D.T. Ray. 1992. Natural tetraploid muskmelons. HortScience 27:47-50.

Schreiter, J., B. Munzert, and A. Moll. 1989. Bestimmung des Ploidiegrades durch Chloroplastenzahlungen in Stomata bei In-vitro-Kallusregeneraten von Kartoffeln. Arch. Züchtungsforsch., Berlin 19:6973. 